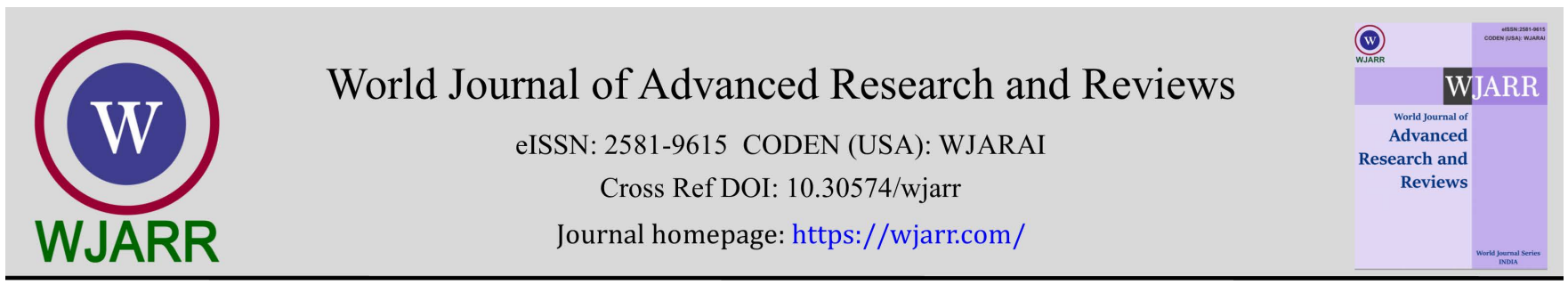

(RESEARCH ARTiClE)

Check for updates

\title{
Geotechnical characterization of soils in the northern zone of Brazzaville
}

\author{
Kempena Adolphe ${ }^{1,}{ }^{*}$, Mbilou G. Urbain ${ }^{1}$, Bissombolo T. dorjeanny ${ }^{1}$, Antonio 0. Gonçalves ${ }^{2}$ and Boudzoumou \\ Florent 1
}

${ }^{1}$ Department of Geology, Faculty of Sciences and Technics, Marien Ngouabi University, Brazzaville-Congo.

2 Department of Geology, Faculty of Sciences, Agostinho Neto University, Luanda-Angola.

World Journal of Advanced Research and Reviews, 2021, 12(01), 086-096

Publication history: Received on 24 August 2021; revised on 29 September 2021; accepted on 01 October 2021

Article DOI: https://doi.org/10.30574/wjarr.2021.12.1.0486

\begin{abstract}
The geotechnical classification of soils by laboratory tests is usually used to determine the class of the soil under study for its subsequent use in construction projects. The interest is certainly well displayed. Indeed, an experimental program has been developed with the aim of studying the soil in the study area. To this end, oedometric and shear tests were carried out on several soil samples in the laboratory. This made it possible to understand the "stress-strain" behavior of these soils. As a result, the presence of a silty sand soil was found that is susceptible to collapse.
\end{abstract}

Keywords: Soils; Sity sand; Oedometric tests; stress-strain; Collapse

\section{Introduction}

Soil is the oldest building material in existence and at the same time one of the most complex due to the variability of its properties and great diversity. The soil has always been the object of interrogation and research in all civilizations. Before building men have always been concerned with soil problems. The development of geotechnic engeneering has been limited mainly in saturated soils due to the difficulties of experimentation and interpretation of measurements. However, it is essential to take into account the soil behavior before the structures implantation [1].

\section{Material and methods}

\subsection{Study area}

The city of Brazzaville is located on the right bank of the Congo River downstream of the Stanley Pool. It is located in cartographic zone $33 \mathrm{~S}$ and has a latitude between $4^{\circ} 11^{\prime} 45^{\prime \prime}$ and $4^{\circ} 18^{\prime} 45^{\prime \prime}$ South and a longitude between $15^{\circ} 11^{\prime} 15$ " and $15^{\circ} 18^{\prime} 45^{\prime}$ East (Figure 1). The study area has a climate of the Lower Congolese or Sudano Guinean type, characterized by two seasons as a long rainy season from October to May, interrupted by a small dry season from January to February and a long dry season from June to September [2]. It is found a contrasting landscape juxtaposing the reliefs of plateaus and plains [3]. The groundwater in the region is a veritable Congo water tower from which the large rivers of Congo and Gabon originate [4]. The soils are varied and we can distinguish soils formed on polymorphic Batéké sands with a clay content and very low mineral reserves, soils formed on Inkisi sandstone with a sandy-clay texture, soils formed on heterogeneous alluvial deposits of the Congo River and its tributaries. These soils are generally sandy clay poor in organic matter [5,6]. The geological formations encountered in the region are divided into three large sedimentary series which from the base to the top appear respectively the Inkisi Formation, the Stanley-Pool Series and the Batéké Plateaus Series [7,8,9].

${ }^{*}$ Corresponding author: Kempena A

Departement of Geology, Faculty of Sciences and Technics, Marien Ngouabi University, Brazzaville-Congo.

Copyright (@ 2021 Author(s) retain the copyright of this article. This article is published under the terms of the Creative Commons Attribution Liscense 4.0. 


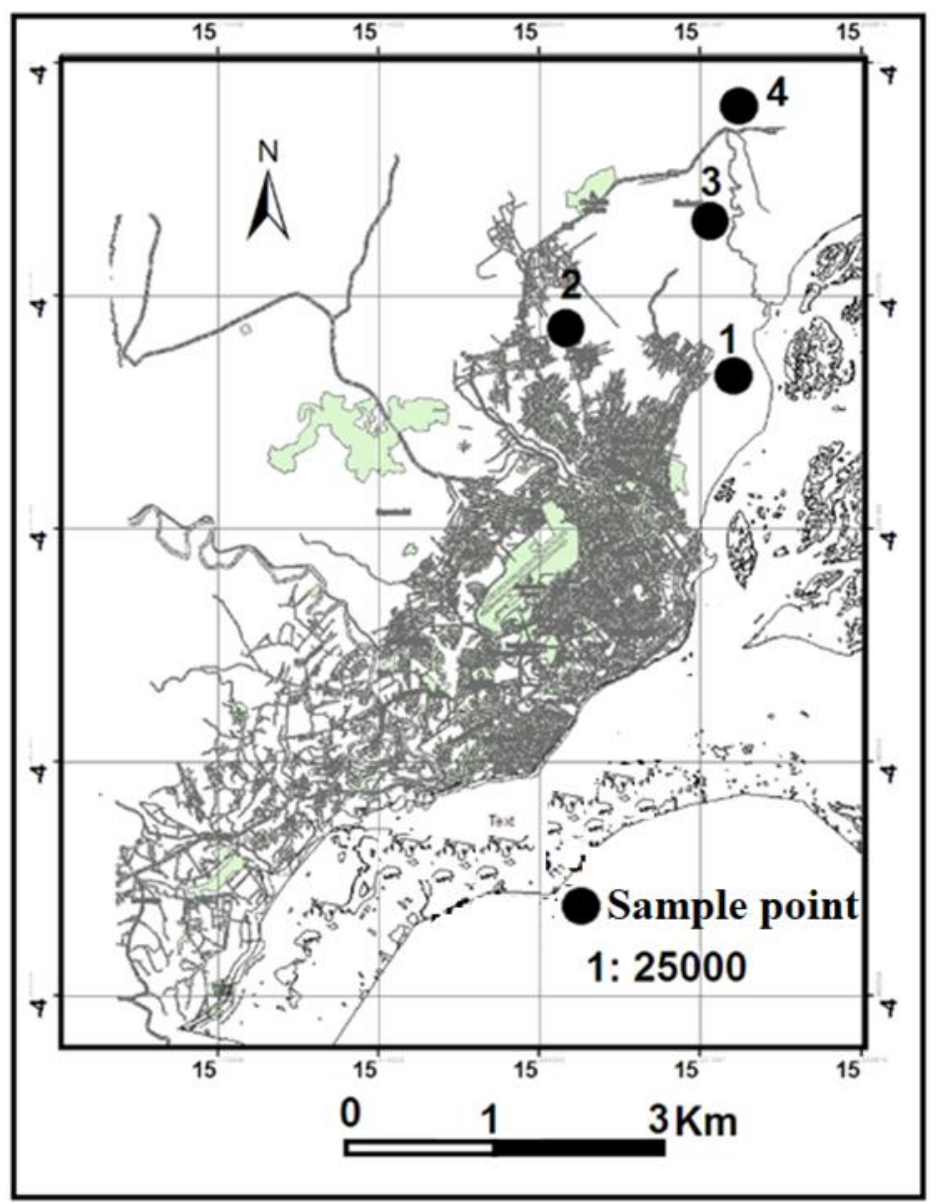

Figure 1Study area Location

\subsection{Materials}

The first experimental phase consists of identifying the soil through a series of tests to determine its physico-mechanical properties.

\subsubsection{Laboratory tests}

The different tests carried out in the laboratory are: Particle size analysis, Methylene Blue value, specific densities of solid grains, Atterberg limits, Proctor test and Shear test.

\subsection{Laboratory study resources}

The purpose of laboratory tests is to determine the physical and mechanical parameters of the soil in order to estimate its natural state. These tests are carried out on representative samples taken from the trenches in order to obtain precise and reliable results.

\subsubsection{Experimental study}

The laboratory tests used to contribute to a better knowledge of the soil rheology are the identification tests like the water content, grain size, sedimentometry, VBS, Atterberg limits and the direct shear as a mechanical test.

\subsection{Identification tests}

This procedure obviously required taking intact samples from soil to a depth of $0.5 \mathrm{~m}$. These classic soil mechanics tests then allowed the soil identification.

So we have: 
The water content by steaming

The water content of a soil = percentage of water (by mass) in relation to dry material.

$\mathrm{W}(\%)=($ mass of water contained $/$ mass of soil solid particles $) \times 100($ NFP94-050).

Determination of the water content $(\mathrm{W})$ expressed as a percentage:

$$
\mathrm{w}(\%)=\frac{\mathrm{p}_{2}-\mathrm{p}_{3}}{\mathrm{p}_{3}-\mathrm{p}_{1}} \times 100
$$

With:

$\mathrm{P}_{1}$ : mass of the recipient

$\mathrm{P}_{2}$ : mass of the recipient + mass of the soil. (P2-P3 / P3-P1) * 100

$\mathrm{P}_{3}$ : mass of the recipient + mass of the dry soil.

$\mathrm{P}$ paraffin $=\mathrm{P}($ Wet + Paraffin $)-$ Pwet

Gross volume $=\mathrm{P}($ Wet + Paraffin $)-\mathrm{P}$ material in water

Net volume $=($ Gross volume $)$ - (Paraffin volume $)$

Particle size test by sieving

The aim is to determine the quantity (mass) of grains per diameter up to $80 \mu \mathrm{m}$ (NFP94-056/1996).

\subsubsection{Equipment used}

Sieve, square mesh screens, common dimensions (80 mm - $50 \mathrm{~mm}, 32 \mathrm{~mm}-20 \mathrm{~mm}, 10 \mathrm{~mm}-5 \mathrm{~mm}, 2 \mathrm{~mm}-1 \mathrm{~mm}, 0.4$ $\mathrm{mm}-0.2 \mathrm{~mm}-0.08 \mathrm{~mm}$ ) and a balance.

Particle size test by sedimentometry

The ai mis to determine the weight distribution of soil grains according to their size for fine particles smaller than 0.08 mm (NFP94-057 / 1992).

Methylene blue test (NF P 94 -068)

The purpose of the methylene blue test is to determine the argilosity and therefore the level of fine particles. The VBS (Soil Blue Value) was determined from the methylene blue spot test on a $0 / 2 \mathrm{~mm}$ fraction.

\subsubsection{Materials used}

Andreasen pipette, white filter paper, glass rod, cylindrical glass container, magnetic stirrer and beaker. The results are expressed as the dry mass of the test sample $(\mathrm{MO}=\mathrm{M} 1 /(1+\mathrm{w}))$, mass of blue introduced $(\mathrm{B}=0.01 \times \mathrm{V})$. The results are expressede in $\mathrm{g}$ of blue for $100 \mathrm{~g}$ of dry soil (VBS $=100 \mathrm{xB} / \mathrm{MO})$. The following values can be distinguished:

VBS $<0.1$ : soil insensitive to water

$0.2 \leq$ VBS $<1.5$ (sandy loam soil, sensitive to water)

$1.5 \leq$ VBS $<2.5$ (sandy clay soil, not very plastic)

$2.5 \leq$ VBS $<6$ (loamy soil of medium plasticity)

$6 \leq \mathrm{VBS}<8$ (clay soil) and VBS $>8$ (very clayey soils).

Atterberg limits (NFP94-057)

The Atterberg limits are characteristic water contents of fine soils which among other things make it possible to establish their classification and assess their consistency. This is a relatively long test to perform (usually more than two days and the duration increases with the proportion of clay). The results obtained are repeatable and reproducible. The Atterberg limits include the liquidity limit (WL), the plasticity limit (WP) and the plasticity index (PI) that corresponds to the difference between the liquidity limit and the plasticity limit. For all the water contents between 
these two limits the material will be in a plastic state. It is important to recognize that the larger the gap the higher the plasticity of the soil.

\subsubsection{Material used}

The Cassagnande apparatus itself consisting of a heavy base, a guiding and adjustment mechanism. There are a smooth cup, a stroke counter available in 2 versions (manual or motorized), a set of accessories specific (grooving tools), rough cup, jig for checking the drop height of the cup $(10 \mathrm{~mm})$, balance, recipients, the oven with temperature control and the spatula.

\subsubsection{Plasticity index Ip}

The plasticity index noted Ip, is the parameter most commonly used to characterize fine soils. It is expressed as $I p=W l-$ $W p$

\subsubsection{Mechanical tests}

These tests were made in order to obtain a better knowledge of the mechanical behavior of the soil studied at the Laboratoire Géoconsul de Pointe-Noire.

\section{Standard Proctor test}

The Proctor test is carried out according to the standard NF P 94-093. The purpose of this test is to determine the optimum water content and the maximum density of a material subjected to standardized compaction of a given intensity. The results are then reported in a graph (dry density as a function of water content) showing a maximum d $\gamma$ for a water content Wopt.

\section{Shear test}

This test makes it possible to obtain the cohesion (C) and the internal friction angle $(\varphi)$ by the tangent of the friction angle. Depending on the normal stress applied to the fracture plane from the Mohr-Coulomb curve we obtain the soil cohesion (c) and the internal friction angle $(\varphi)$.

\section{Odometric tests}

The main purpose of this test is to determine the soil characteristics for calculating the soil settlements under the load weight (Foundation, embankment, etc....). A series of oedometric tests was carried out at the road geotechnical laboratory of Agostinho Neto University in Luanda (Kilamba). The equipment used is a Wickram France type rear loading oedometer. The loading is of the incremental type by addition of masses. The mass reading is visual on mechanical comparators to $1 / 100$ th.

\section{Results and discussion}

\subsection{Physical properties}

Initial water content $(\mathrm{w} \%)=5.8$, Particle size analysis $($ Table 1$)$

Table 1Particle size distribution of the soil by sieving

\begin{tabular}{|c|c|c|c|c|c|}
\hline \multirow[t]{2}{*}{$\mathbf{N}^{\circ}$} & \multirow{2}{*}{$\begin{array}{c}\text { Screen } \\
\text { openings } \\
(\mathrm{mm})\end{array}$} & \multirow{2}{*}{$\begin{array}{c}\text { Sample } \\
\text { mass } \\
\text { (g) }\end{array}$} & \multirow{2}{*}{$\begin{array}{c}\text { Total refusal mass } \\
\text { in }(\mathrm{g})\end{array}$} & \multicolumn{2}{|c|}{ Mass percentage $(\%)$} \\
\hline & & & & $\begin{array}{l}\text { Cumulative } \\
\text { refusal }\end{array}$ & $\begin{array}{l}\text { Cumulative } \\
\text { sieving }\end{array}$ \\
\hline 1 & 1 & \multirow{4}{*}{400} & 7.7 & 1,93 & 98.07 \\
\hline 2 & 0.4 & & 42.3 & 10.58 & 89.43 \\
\hline 3 & 0.2 & & 215 & 53.75 & 46.25 \\
\hline 4 & 0.08 & & 244 & 61 & 39 \\
\hline
\end{tabular}


The grain size curve is shown in Figure 2.The particle size curve identified the type of material that is a granular class and its nature. In our case we have a fine silty sand because of having tight curves, classifying the uniform material with sediments of similar sizes well graduated.

The combination of sieving and sedimentometry gives the values shown in Table 2.

Table 2 Particle size distribution of the soil studied

\begin{tabular}{|l|l|c|}
\hline \multicolumn{1}{|c|}{ Grain size } & Soil type & Screening + Sedimentometry \\
\hline Grain $<2 \mu \mathrm{m}$ & Clay & $4 \%$ \\
\hline $2 \mu \mathrm{m}<$ Grains $<63 \mu \mathrm{m}$ & Limon & $17 \%$ \\
\hline $63 \mu \mathrm{m}<$ Grains & Sable & $78 \%$ \\
\hline
\end{tabular}

Coefficient of uniformity $(\mathrm{Cu}=\mathrm{D} 60 / \mathrm{D} 10=3.3)$

Curvature coefficient $(\mathrm{Cc}=(\mathrm{D} 30) 2 / \mathrm{D} 60 . \mathrm{D} 10=1.8)$

Our soil is well graduated.

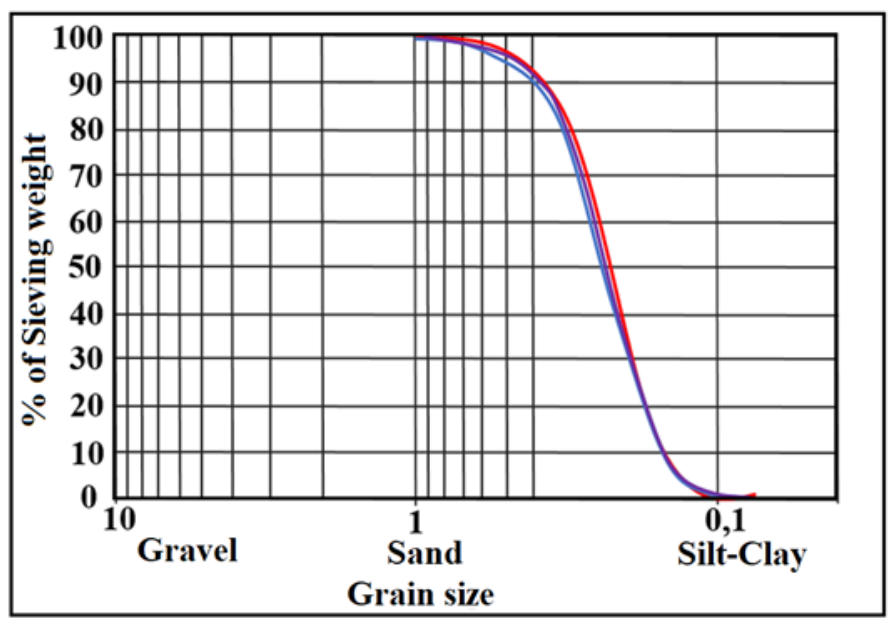

Figure 2 Grain size curve of the soil in the study area

Methylene blue test:

The values of the methylene blue test being $0.2 \leq \mathrm{VBS}<1.5$; therefore the soil in our study area is a silty sand and sensitive to water.

Specific densities of solid grains pycnometer method (Table 3)

Table 3 Absolute density of the soil

\begin{tabular}{|c|c|c|c|c|c|c|}
\hline Samples & Mo & Ms & $\mathbf{M}_{1}$ & $\mathbf{M}_{2}$ & $\gamma s\left(\mathrm{~g} / \mathrm{cm}^{3}\right)$ & Average \\
\hline Sample 1 & 69,07 & 99,56 & 194,69 & 176,285 & 2,52 & \multirow{4}{*}{2,62} \\
\hline Sample 2 & 68,13 & 105,82 & 198,88 & 175,44 & 2,64 & \\
\hline Sample 3 & 68,24 & 102,34 & 196,95 & 175,48 & 2,7 & \\
\hline Sample 4 & 69,05 & 102,30 & 194,60 & 176,62 & 2,61 & \\
\hline
\end{tabular}


Atterberg limits (Table 4)

Table 4 Results of coefficients and consistency limits

\begin{tabular}{|l|c|c|c|c|}
\hline Physical properties & Sample 1 & Sample 2 & Sample 3 & Sample 4 \\
\hline $\mathrm{Cu}$ & 3.2 & 4.1 & 2.7 & 3.1 \\
\hline $\mathrm{Cc}$ & 1.6 & 1.8 & 1.5 & 1.7 \\
\hline Liquidity limit (WL) & 18 & 16 & 19 & 17 \\
\hline Plastic limit (Wp) & 13 & 11 & 14 & 12 \\
\hline Plasticity Index (PI) & 5.0 & 5.0 & 5.0 & 5.0 \\
\hline
\end{tabular}

\subsection{Mechanical tests}

\subsubsection{Normal Proctor Test}

The results of the standard Proctor test parameters for natural soil are shown in the following table.

Table 5 The results of the parameters of the standard Proctor test for the soil

\begin{tabular}{|l|l|l|l|l|}
\hline Percentage of water added at each compaction & $\mathbf{4 \%}$ & $\mathbf{6 \%}$ & $\mathbf{8 \%}$ \\
\hline Total wet mass (g) & 3480 & 3520 & 3540 \\
\hline Mold mass (g) & 1772 \\
\hline Wet soil mass (g) & 1708 & 1748 & 1768 \\
\hline Mold volume $\left(\mathrm{cm}^{3}\right)$ & 955 & \multicolumn{3}{|l|}{} \\
\hline Mass of dry soil (g) & 2500 \\
\hline Body of water (g) & 100 & 150 & 200 \\
\hline Dry density & 1.72 & 1.73 & 1.71 \\
\hline
\end{tabular}

The compaction curve is obtained from 6 data contained in the table below. From the curve below, we can deduce the maximum dry density $1.73 \mathrm{~g} / \mathrm{cm} 3$ which corresponds to an optimum water content of 5.8, rounded to $6 \%$ (Figure 3).

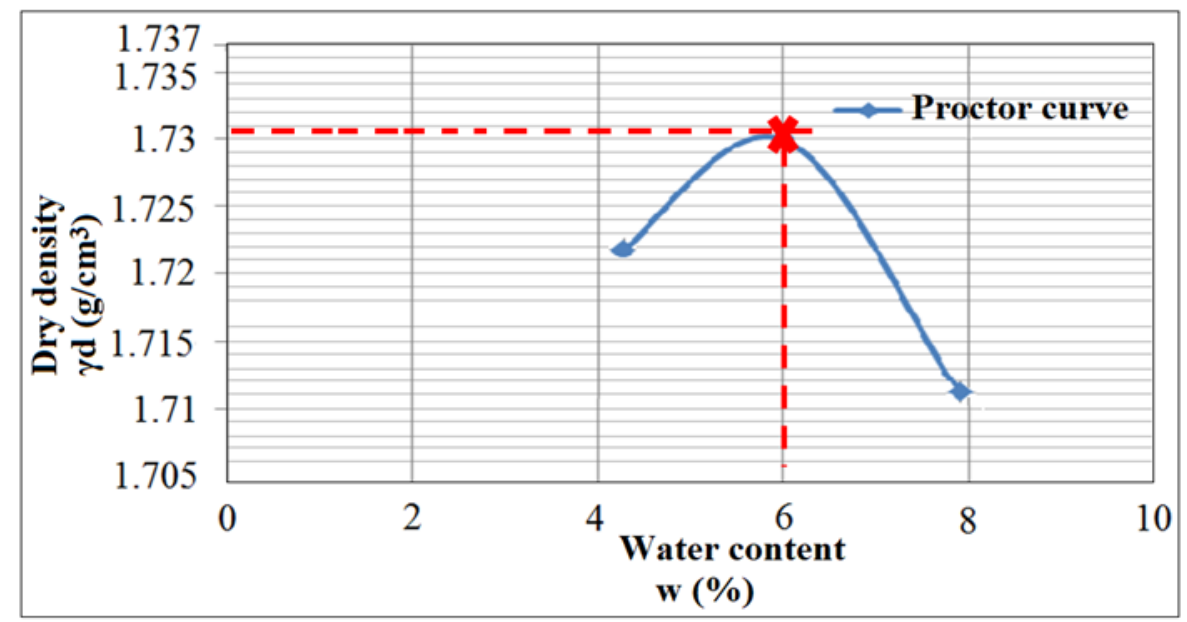

Figure 3Compaction curve (Normal Proctor test) 


\subsubsection{Standard Proctor Test Results}

Maximum dry density $\gamma \mathrm{dmax}=1.73 \mathrm{~g} / \mathrm{cm} 3$

Optimal water content Wopt $=6 \%$

\subsubsection{Shear test}

The purpose of the test is to measure the fracture characteristics of a sample of saturated soil subjected to direct shear along an imposed plane at a constant speed (Figure 4).

Table 6 The sample initial characteristics

\begin{tabular}{|l|c|c|c|}
\hline \multicolumn{1}{|c|}{ Sample } & $\mathbf{1}$ & $\mathbf{1}$ & $\mathbf{1}$ \\
\hline Vertical stress $\left(\mathrm{kN} / \mathrm{m}^{2}\right)$ & 100 & 200 & 300 \\
\hline Wet weight + mold $(\mathrm{g})$ & 149.4 & 149.4 & 149.4 \\
\hline Mold weight $(\mathrm{g})$ & 46 & 46 & 46 \\
\hline Net weight $(\mathrm{g})$ & 103.4 & 103.4 & 103.4 \\
\hline Volume $(\mathrm{cm} 3)$ & 56.52 & 56.52 & 56.52 \\
\hline Wet Density $\gamma \mathrm{h}\left(\mathrm{g} / \mathrm{cm}^{3}\right)$ & 1.531 & 1.531 & 1.531 \\
\hline Water content w $(\%)$ & 5.8 & 5.8 & 5.8 \\
\hline Dry density $\gamma \mathrm{d}\left(\mathrm{g} / \mathrm{cm}^{3}\right)$ & 1.37 & 1.37 & 1.37 \\
\hline Degree of saturation Sr $(\%)$ & 28 & 28 & 28 \\
\hline
\end{tabular}

The shear stress evolution as a function of displacement is represented in the figure 4 . We can note the existence of very pronounced peaks of tangential stresses. The displacements corresponding to these peaks are between $2.8 \mathrm{~mm}$ for $\sigma_{3}=$ $300 \mathrm{kPa}, 2.2 \mathrm{~mm}$ for $\sigma_{2}=200 \mathrm{kPa}$ and $1.9 \mathrm{~mm}$ for $\sigma_{1}=100 \mathrm{kPa}$. The shear stress at fracture obviously increases when the initial normal stress increases and then decreases until reaching the residual value. We also note that the presence of peaks in the curves shows us that the soil is dense.

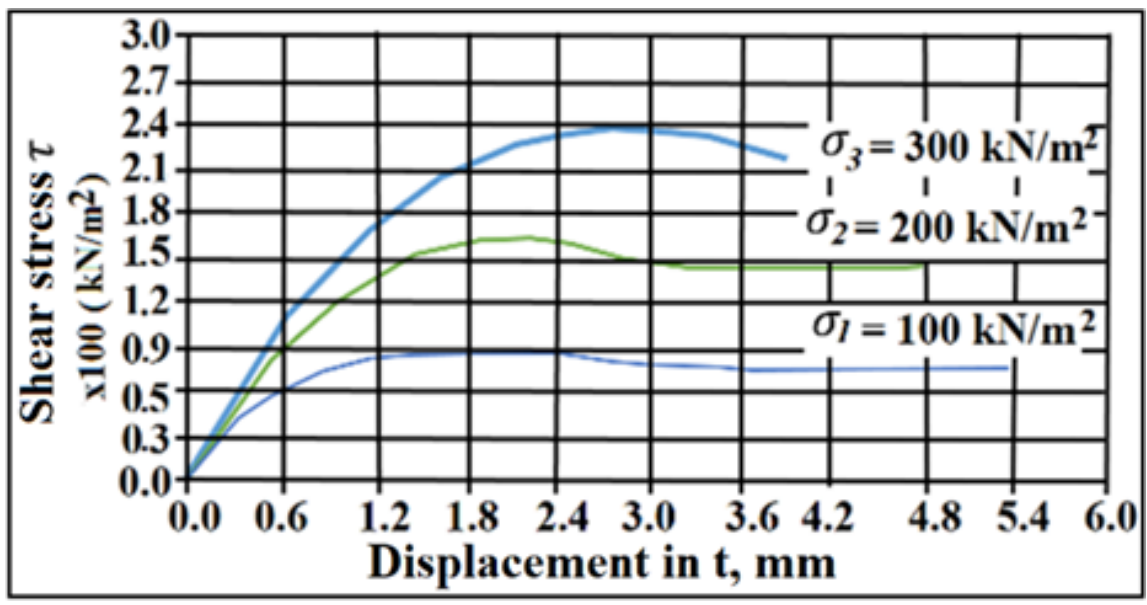

Figure 4Shear/displacement stress curves for natural soil

The Figure 5 presents the envelope curve and determines the two shear parameters like friction angle ( $\varphi$ ) that represents the line slope expressed in degrees, and c is the cohesion. Cohesion reflects the "glue effect" observed in partially saturated soils and it is almost zero for dry sand. 


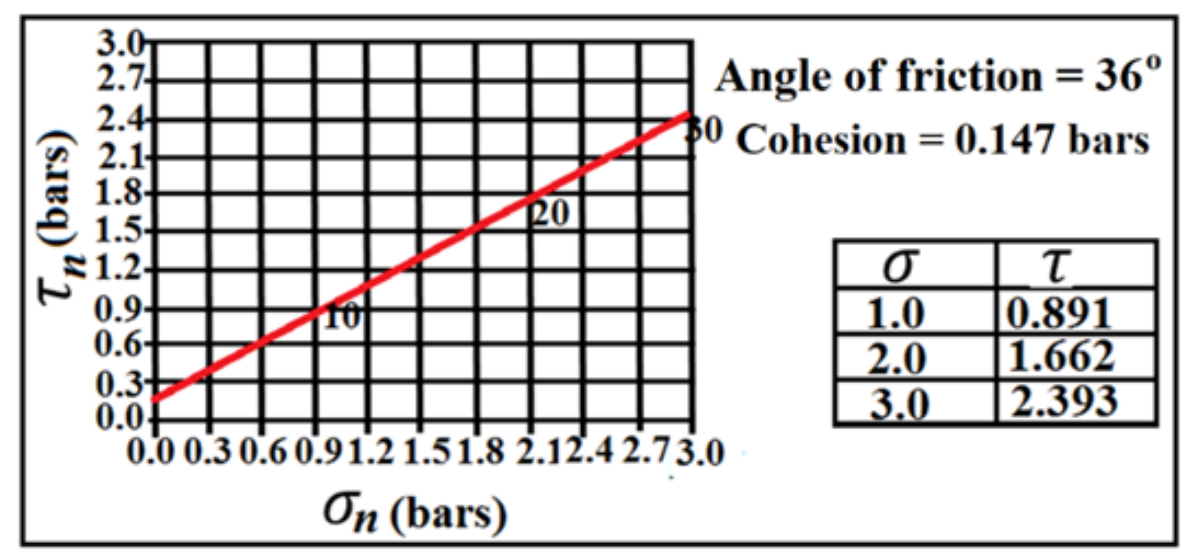

Figure 5 Soil curveenvelope

Angle de frottement : $\varphi=36^{\circ}$

Cohésion : $\mathrm{C}=0.147$ bar $=14.7 \mathrm{kN} / \mathrm{m}^{2}$

\subsubsection{Odometric test}

Most of values found during this test are used to determine settlements. The soil is placed in a rigid envelope that variable pressure is exerted on its upper part using a piston and the subsidence observed after stabilization (Figure 6). The relation between the vertical and the vertical stresses is thus determined.

\subsubsection{Results for untreated soil}

A. Study of collapsible soils: saturated soil at $200 \mathrm{KPa}$ before compaction

Table 7 Characteristic of saturated soil at $200 \mathrm{KPa}$ before compaction

\begin{tabular}{|l|c|c|c|c|}
\hline \multicolumn{1}{|c|}{ Samples } & Sample 1 & Sample 2 & Sample 3 & Sample 4 \\
\hline $\begin{array}{l}\text { Vertical stress (kg / } \\
\mathrm{cm} \text { ) }\end{array}$ & $\begin{array}{c}0.25,0.5,1.0,2.0, \\
4.0,8.0,16\end{array}$ & $\begin{array}{c}0.25,0.5,1.0,2.0, \\
4.0,8.0,16\end{array}$ & $\begin{array}{c}0.25,0.5,1.0,2.0, \\
4.0,8.0,16\end{array}$ & $\begin{array}{c}0.25,0.5,1.0,2.0, \\
4.0,8.0,16\end{array}$ \\
\hline $\begin{array}{l}\text { Specific weight of the } \\
\text { sample }\end{array}$ & 2.6 & 2.6 & 2.6 & 2.6 \\
\hline Initial void index, e & 0.75 & 0.581 & 0.581 & 0.61 \\
\hline Water content W (\%) & 6 & 6 & 6 & 6 \\
\hline Compression index, Cc & 0.35 & 0.18 & 0.23 & 0.20 \\
\hline Collapse coefficient & 8.17 & 4.17 & 6.1 & 4.3 \\
\hline
\end{tabular}




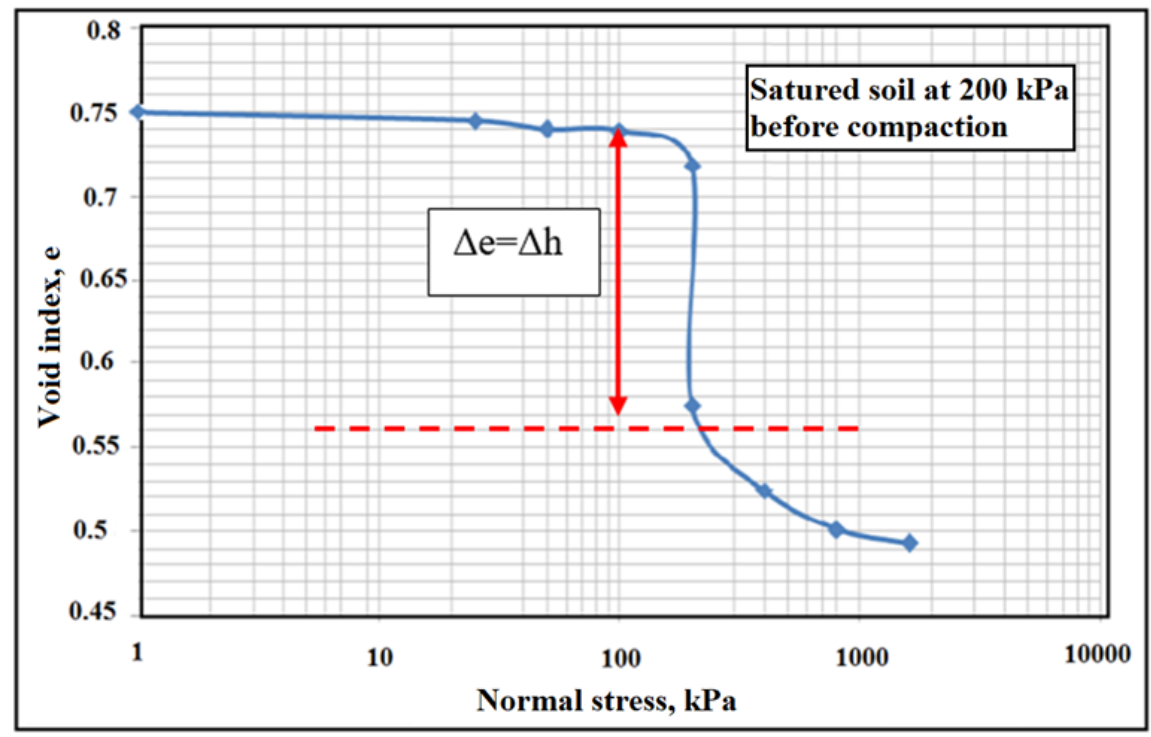

Figure 6 Saturated soil curve at $200 \mathrm{KPa}$ before compaction

B: Study of collapsible soils: saturated soil at 200KPa after compaction

In theFigure 7 there is a considerable reduction in the void index.

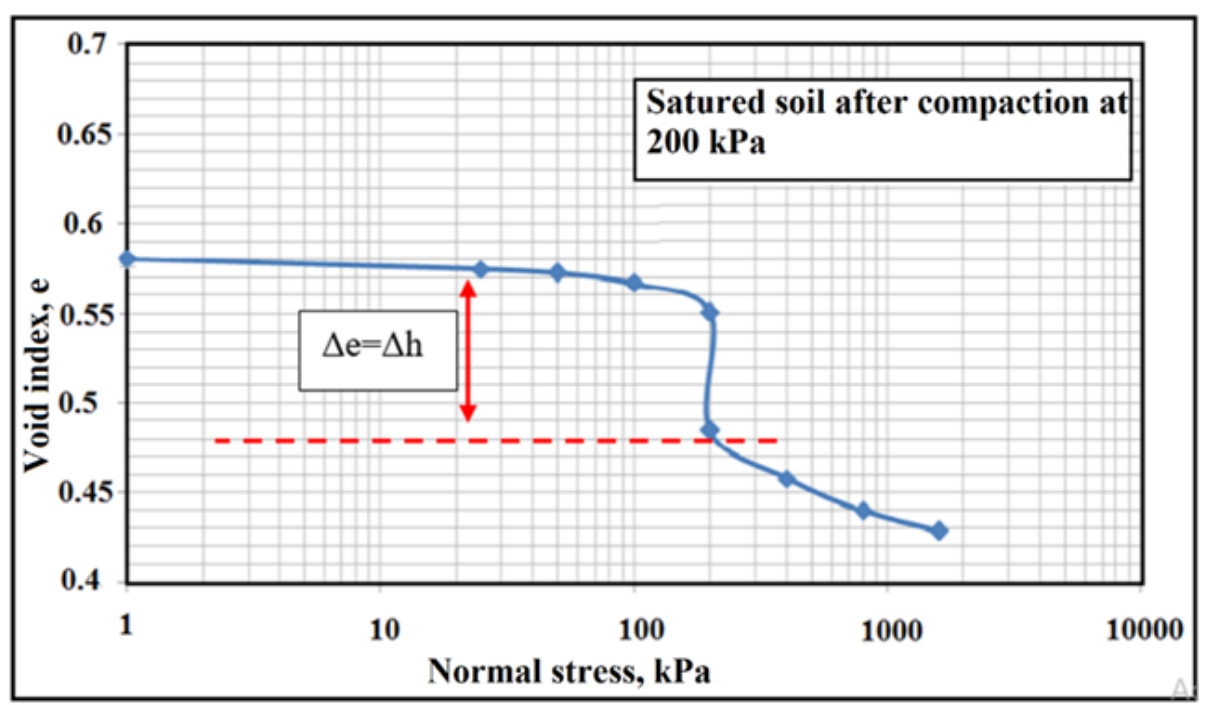

Figure 7 Saturated soil curve at $200 \mathrm{KPa}$ after compaction

The figure 7 shows the condition of the soil. It shows two curves, one for the condition of natural water content and the other for the condition of saturated water content. These curves reflect the collapse. That is to say the collapse is a function of the water content since the saturated state curve shows that when the collapsible soil receives water it becomes unstable. As a result it is the victim of sudden collapse due to the decrease in its shear strength. 


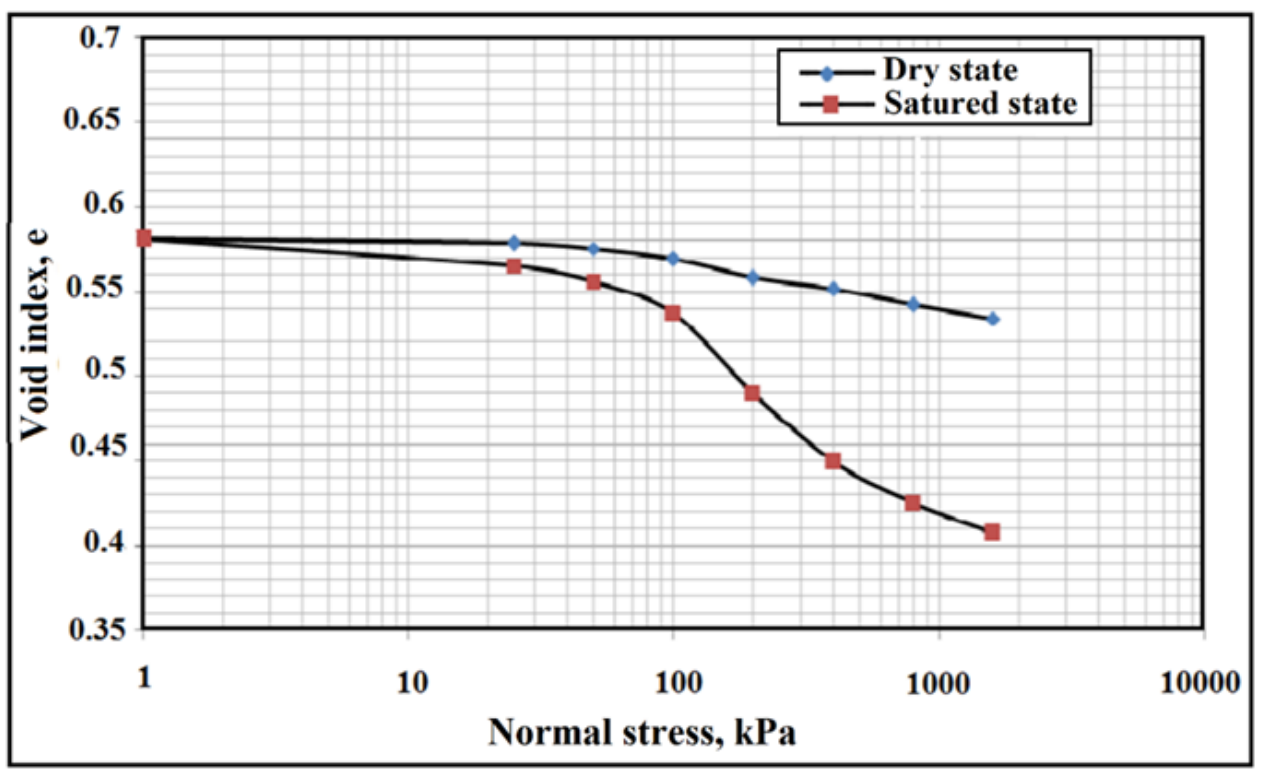

Figure 8 Double Odometer Test Curve

\section{Discussion}

The soils geotechnical parameters are determined by conventional geotechnical tests in the laboratory. Thanks to these geotechnical parameters it can be shown that the soils are susceptible to potential collapse. The results presented in Table 6 show that the soil of our study area is susceptible to potential collapse and are verified which confirms in the literature [10]. It is concluded that "for any relative density and water content during sample preparation there is a critical stress at which the collapse value is at its maximum." This critical stress is equal to the stress developed during the compaction of the sample and decreases as the water content increases for a constant relative density. For a constant water content when the relative density increases the collapse intensity decreases [11].

\section{Conclusion}

Soil collapse is a very complex phenomenon that involves a large number of intrinsic and surrounding parameters. The purpose of this research is to illustrate that it is possible to understand the behavior of a soil in the face of collapse from the results of geotechnical laboratory tests. The behavior of the control soils (without treatment) corroborates with certain existing results in the bibliography. The studies that have been carried out as identification tests, consistency and compressibility characteristics confirm the character and collapsible behavior of the soil studied. Furthermore, based on these data we were able to conclude that the compaction mode and the oedometer test allow a very satisfactory description of the collapse of the reconstituted soil.

\section{Compliance with ethical standards}

\section{Acknowledgments}

The authors gratefully acknowledge the Geotechnical laboratory of the buildings and public works office, Brazzaville, Congo, for experimental tests.

\section{Disclosure of conflict of interest}

The authors declare that there is no conflict of interests regarding the publication of this paper.

\section{References}

[1] Messast S. Rheology of collapsible soils, applications for foundations design. [Ph.D. dissertation]. Algeria: August twentieth University; 1955.

[2] Samba Kimbata M. The Bas Congo climate [Ph.D. dissertation]. C.R.C of Dijon: Burgundy University; 1978. 
[3] Denis B. Explanatory note of the Pedological map of Brazzaville-Kinkala, Popular Republic of Congo at 1/200,000. Paris: ORSTOM. 1974; 101.

[4] Moukolo N. State of current knowledge on the hydrogeology of Congo Brazzaville. Hydrogeology. Brazzaville; 1992. P. 58- 2.

[5] Denis B. Explanatory note of the Brazzaville-Kinkala soil map. People's Republic of the Congo. Paris: ORSTOM; 1974.

[6] Schwartz D. Soils around Brazzaville and their uses. Pointe-Noire: Popular Republic of Congo; 1987.

[7] Cosson J. Explanatory note about Pointe-Noire and Brazzaville. Geological acknowledgement map at 1/500,000. Brazzaville: Department of Mines and Geology. A.E.F; 1955.

[8] Marshal A. Contribution to Batékés plateau study (Geology, geomorphology, hydrogeology). Brazzaville: ORSTOM; 1966.

[9] Dadet P. Explanatory note of Geological map of Republic of Congo Brazzaville at 1/500 000. Paris: Reports of BRGM; 1969.

[10] Ayadat T. and Ouali S. Identification of collapsible soils based on the Atterberg limits. French geotechnical review. 1999 Sept; 86(3).

[11] Abbeche K, Hammoud F, Ayadat T. Influence of relative density and lay fraction on soils collapse. Experimental unsaturated soil mechanics. Springer Proceedings in Physics. 2007; (7):112-9. 